Chronic Obstructive Pulmonary Diseases: Journal of the COPD Foundation

\author{
Original Research
}

\title{
Improvements in Lung Function with Nebulized Revefenacin in the Treatment of Patients with Moderate to Very Severe COPD: Results from Two Replicate Phase III Clinical Trials
}

Gary T. Ferguson, $\mathrm{MD}^{1}$ Gregory Feldman, $\mathrm{MD}^{2}$ Krishna K. Pudi, $\mathrm{MD}^{3}$ Chris N. Barnes, $\mathrm{PhD}^{4}$ Edmund J. Moran, $\mathrm{PhD}^{4}$ Brett Haumann, MD, MBA ${ }^{4}$ Srikanth Pendyala, $\mathrm{MD}^{4}$ Glenn Crater, $\mathrm{MD}^{4}$

\section{Abstract}

Background: Revefenacin, a novel, lung-selective, long-acting muscarinic antagonist, has been developed for nebulized therapy for chronic obstructive pulmonary disease (COPD). We present the results of replicate Phase III efficacy and safety studies of revefenacin in patients with moderate to very severe COPD.

Methods: In 2 double-blind, parallel-group studies, (Study 0126 and Study 0127), patients $\geq 40$ years old were randomized to revefenacin $88 \mu \mathrm{g}$, revefenacin $175 \mu \mathrm{g}$ or placebo administered once daily by standard jet nebulizer for 12 weeks. The primary endpoint was 24-hour trough forced expiratory volume in 1 second (FEV $)$ on day 85. Secondary efficacy endpoints included overall treatment effect (OTE) on trough FEV 1 and peak FEV 1 (0-2 hours after first dose). Safety assessments included treatment-emergent adverse events.

Results: At day 85, revefenacin $88 \mu \mathrm{g}$ and $175 \mu \mathrm{g}$ improved trough FEV 1 versus placebo in Study 0126 (by 79 $\mathrm{mL}[p=0.0003]$ and $146 \mathrm{~mL}[p<0.0001]$ ) and Study 0127 (by $160 \mathrm{~mL}$ and $147 \mathrm{~mL}$; both $p<0.0001$ ). Compared with placebo, pooled data of revefenacin $88 \mu \mathrm{g}$ and $175 \mu \mathrm{g}$ increased OTE trough FEV 1 by $115 \mathrm{~mL}$ and 142 $\mathrm{mL}$ (both $p<0.001$ ) and increased peak FEV 1 by $127 \mathrm{~mL}$ and $129 \mathrm{~mL}$ (both $p<0.0001$ ). Revefenacin $175 \mu \mathrm{g}$ demonstrated greater improvements in $\mathrm{FEV}_{1}$ in concomitant long-acting beta2-agonist patients and in more severe patients than revefenacin $88 \mu \mathrm{g}$. Adverse events were minor.

Conclusions: Revefenacin, administered once daily for 12 weeks to patients with moderate to very severe COPD, demonstrated clinically significant improvements in trough $\mathrm{FEV}_{1}$ and OTE FEV . Revefenacin was generally well tolerated with no major safety concerns.

\begin{abstract}
Abbreviations: chronic obstructive pulmonary disease, COPD; forced expiratory volume in 1 second; FEV $\mathbf{1}$; overall treatment effect, OTE; Global initiative for chronic Obstructive Lung Disease, GOLD; long-acting muscarinic antagonist, LAMA; long-acting beta2-agonist, LABA; inhaled corticosteroid, ICS; adverse event, AE; Medical Dictionary for Regulatory Activities, MedDRA; intention-to-treat, ITT; revefanacin, REV; standard deviation, SD; body mass index, BMI; forced vital capacity, FVC; modified Medical Research Council dyspnea scale, mMRC; COPD Assessment Test, CAT; least squares, LS; standard error, SE; confidence interval, CI; serious adverse event, SAE; gastrointestinal, GI Funding Support: This study was funded by Theravance Biopharma, Inc. (Dublin, Ireland). Mylan Inc., (Canonsburg, Pennsylvania) and Theravance Biopharma (South San Francisco, California) funded medical writing support.

Date of Acceptance: February 22, 2019

Citation: Ferguson GT, Feldman G, Pudi KK, et al. Improvements in lung function with nebulized revefenacin in the treatment of patients with moderate to very severe COPD: results from two replicate phase III clinical trials. Chronic Obstr Pulm Dis. 2019;6(2):154-165. doi: https://doi.org/10.15326/jcopdf.6.2.2018.0152
\end{abstract}

1 Pulmonary Research Institute of Southeast Michigan, Farmington Hills

2 South Carolina Pharmaceutical Research, Spartanburg
3 Sherman Clinical Research, Sherman, Texas

4 Theravance Biopharma US, Inc., South San Francisco, California 


\section{Address correspondence to:}

Gary T. Ferguson, MD

Suite A

29255 West 10 Mile Road

Farmington Hills, MI 48336

Email: garytferguson@msn.com

Phone: (248) 478-6561

\section{Keywords:}

revefenacin; chronic obstructive pulmonary disease; COPD; nebulized therapy; forced expiratory volume in 1 second; $\mathrm{FEV}_{1}$; Phase III randomized controlled trial

\section{This article contains an online supplement.}

\section{Introduction}

Chronic obstructive pulmonary disease (COPD) is a common and treatable disease characterized by airflow limitation and respiratory symptoms. ${ }^{1}$ The Global initiative for chronic Obstructive Lung Disease (GOLD) consensus report recommends the use of long-acting muscarinic antagonist (LAMA) and/or long-acting beta2-agonist (LABA) bronchodilators as first-line therapy for patients with persistent COPD symptoms. ${ }^{1}$ Long-acting inhaled bronchodilators are most often self-administered with hand-held devices such as pressurized metered-dose inhalers or dry powder inhalers ${ }^{2,3}$; however, many patients are challenged by the use of these inhalers (typically due to impaired hand/breath coordination, insufficient inspiratory flow rates or cognitive impairment). ${ }^{4,5}$ These patients may benefit from delivery of their medications via a nebulizer, which may provide improved symptom control and quality of life compared with other modes of delivery. ${ }^{6}$ Current standard battery-powered jet nebulizers are portable, with nearly silent operation, making them more practical for everyday use than previous nebulizers. ${ }^{4,6}$

Revefenacin is a novel, once-daily, lung-selective LAMA in late-stage clinical development for the treatment of patients with COPD. ${ }^{7,8}$ It is designed to produce sustained and localized dilation in the bronchi with minimal systemic drug exposure. ${ }^{9,10}$ In a 4-week Phase II placebo-controlled dose-finding study in patients with COPD, once-daily revefenacin $(88 \mu \mathrm{g}, 175 \mu \mathrm{g}$ and $350 \mu \mathrm{g}$ ) resulted in significant improvements in trough forced expiratory volume in 1 second $\left(F E V_{1}\right) .{ }^{11}$ Here we report the results of 2 replicate 12-week Phase III trials that characterize the efficacy, safety and tolerability of once-daily revefenacin (88 $\mu \mathrm{g}$ and $175 \mu \mathrm{g}$ ) administered by standard jet nebulizer in patients with moderate to very severe COPD.

\section{Methods}

\section{Study Design and Conduct}

Study 0126 (NCT02459080) and Study 0127 (NCT02512510) were Phase III, randomized, doubleblind, placebo-controlled, multiple-dose, parallelgroup studies. Both studies were conducted in accordance with the principles of the International Council on Harmonisation of Technical Requirements for Pharmaceuticals for Human Use guideline for good clinical practice, ${ }^{12}$ and the code of ethics of the World Medical Association's Declaration of Helsinki, ${ }^{13}$ and all patients provided written informed consent. Entry criteria, study design and statistical analyses for both studies were identical. The protocol was reviewed and approved by an institutional review board (Quorum Review IRB, Seattle, Washington).

\section{Patients and Treatments}

Patients were $\geq 40$ years old with documented COPD history, a smoking history of at least 10 pack years, a post-ipratropium $\mathrm{FEV}_{1}$ /forced vital capacity ratio of $<$ 0.7 and a post-ipratropium $\mathrm{FEV}_{1}$ of $<80 \%$ of predicted normal but at least $700 \mathrm{~mL}$ at Visit 1B (online data supplement e-Figure 1), constituting criteria for moderate to very severe COPD. Patients were excluded if they had a history of myocardial infarction or unstable angina within the previous 6 months, unstable or life-threatening cardiac arrhythmia requiring intervention within the previous 3 months, New York Heart Association Class IV ${ }^{14}$ heart failure prior to the start of the study or exhibited an abnormal and clinically significant 12-lead electrocardiogram finding at study entry. If a patient did not meet the eligibility criteria because of a failed screening test, this test or procedure was not permitted to be repeated and the individual was considered ineligible. Failed screening tests resulting in ineligibility included spirometry (i.e., if an individual failed to meet any spirometry-related criteria after the first attempt, the individual was screen failed). Spirometry was assessed during the treatment period at days 1,15 , 29, 57, 84 and 85, which corresponded to Visits 3, 4, 5, 6, 7, and 8, respectively. A telephone follow-up visit was carried out approximately a week after Visit 
8 to review concomitant medications and adverse events (online data supplement e-Figure 1). Patients were randomized $1: 1: 1$ to receive revefenacin $88 \mu \mathrm{g}$, revefenacin $175 \mu \mathrm{g}$ or matching placebo, administered once daily in the morning by a standard jet nebulizer (PARI LC ${ }^{\circledR}$ Sprint, Starnberg, Germany) for 12 weeks. Concomitant LABA-containing therapy (with or without inhaled corticosteroids [ICSs]) was permitted in up to $40 \%$ of the study population to ensure robust assessments of concurrent therapies used by the participants. Once the $40 \%$ limit was reached, new individuals who entered screening required a 14-day washout of any LABA-containing therapy prior to the ipratropium reversibility test at screening. Individuals on ICS/LABA combination therapy enrolled after the $40 \%$ cap was reached had their medication modified to receive only ICS monotherapy at an equivalent dose for at least 14 days, prior to the ipratropium reversibility visit at screening. Stable doses of ICSs without concomitant LABAs were permitted but use of LAMAs and short-acting muscarinic antagonists was prohibited.

\section{Assessments and Endpoints}

The primary efficacy endpoint was change from baseline in trough $\mathrm{FEV}_{1}$ (defined as the mean of the 23.25- and 23.75-hour spirometry assessments following the 84th dose) on day 85. Secondary efficacy endpoints included overall treatment effect (OTE) on trough $\mathrm{FEV}_{1}$ (defined as the inverse-variance weighted average of all the trough $\mathrm{FEV}_{1}$ assessments across days 15 through 85 [15, 29, 57 and 85]) and peak (maximum) $\mathrm{FEV}_{1}$ (0-2 hours post first dose) on day 1. Patient-reported outcomes, which will be reported elsewhere, included rescue albuterol use, the St George's Respiratory Questionnaire, ${ }^{15}$ and the Transition Dyspnea Index. ${ }^{16}$ Additional details on secondary efficacy endpoints are described in the online data supplement.

Safety assessments included treatment-emergent adverseevents (AEs), clinical laboratory measurements, electrocardiograms (reported in a separate paper), vital signs and physical examinations. AEs were coded using preferred terms from the Medical Dictionary for Regulatory Activities (MedDRA ${ }^{\circledR}$ ), Version 18.1. ${ }^{17}$ System organ class, preferred term, relationship to study drug, and severity summarized the frequency and percentage of patients reporting AEs.

\section{Statistical Analysis}

The intention-to-treat (ITT) analysis set included all randomized patients who received at least 1 dose of the study drug (revefenacin or placebo) and had at least 1 recorded post-baseline $\mathrm{FEV}_{1}$ assessment. Assessments of efficacy were performed using the ITT analysis set. Assessments of safety were performed using the safety analysis set, which included all randomized patients who received at least 1 dose of study drug. Additional statistical analyses are described in the online data supplement.

\section{Results}

\section{Patients}

A total of 3256 patients were screened for both studies (Figure 1), of which 619 were randomized to treatment in Study 0126 (revefenacin $88 \mu \mathrm{g}$ [ $\mathrm{n}=212]$, revefenacin $175 \mu \mathrm{g}$ [n=198] and placebo [n=209]) and 611 were randomized to treatment in Study 0127 (revefenacin $88 \mu \mathrm{g}$ [n=205], revefenacin $175 \mu \mathrm{g}[\mathrm{n}=197]$ and placebo $[\mathrm{n}=209])$. One patient randomized to placebo in Study 0127 never received study treatment and was therefore excluded from the final ITT analysis set. Thus, 610 patients contributed efficacy data and were included in the ITT analysis set. Another patient randomized to the revefenacin $175 \mu \mathrm{g}$ group in Study 0127 received the wrong study drug kit at Visit 6 (day 57) and was subsequently dosed with placebo. This patient thus contributed safety data to 2 treatment groups (175 $\mu \mathrm{g}$ and placebo) and, therefore, 611 patients are presented in the Study 0127 safety analysis set. The ITT and safety analysis sets for Study 0126 included 619 patients in both cases.

Patient demographics and baseline characteristics from Studies 0126 and 0127 (Table 1) indicated revefenacin and placebo groups were well balanced across all variables, including demographic background, concurrent LABA and/or ICS use and pulmonary health status. Baseline COPD severity of patients (online data supplement e-Figure 2) demonstrated similar rates of severe airflow limitation (GOLD 3) and very severe airflow limitation (GOLD 4) ${ }^{18}$ in Study 0126 (29.1\% and 4.5\%, respectively) and Study 0127 (34.9\% and 4.1\%, respectively). Similar rates of patients with more symptoms and high risk of exacerbations (2011 GOLD category $D^{18}$ ) were observed between the studies (Study 0126 [31.5\%] and Study 0127 [36.4\%]). 


\section{Figure 1. Patient Disposition}
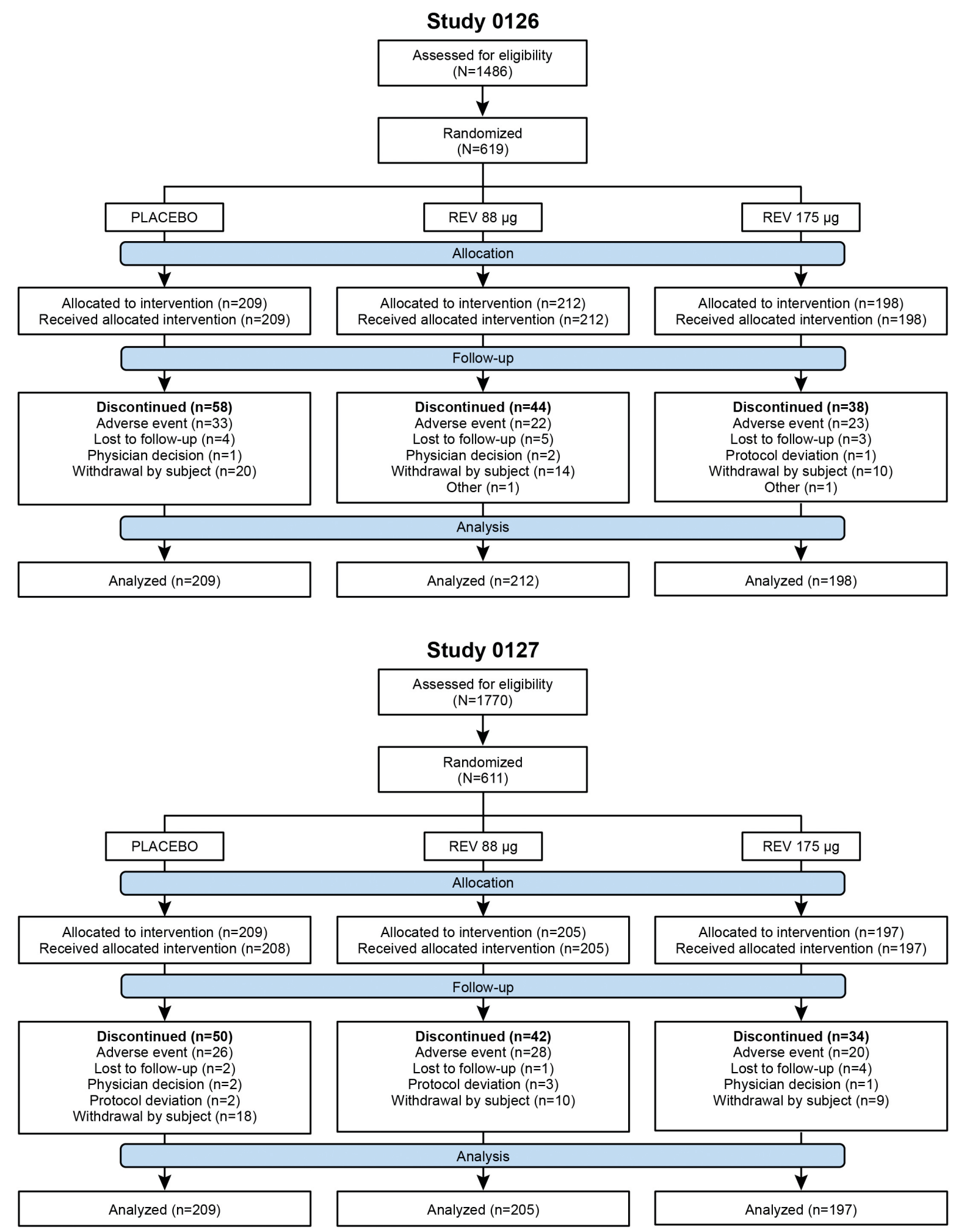


\section{Table 1. Patient Demographics and Baseline Characteristics (Intention-to-Treat Analysis Set)}

\begin{tabular}{|c|c|c|c|c|c|c|}
\hline \multirow[t]{2}{*}{ Characteristic } & \multicolumn{3}{|c|}{ Study 0126} & \multicolumn{3}{|c|}{ Study 0127} \\
\hline & $\begin{array}{l}\text { REV } 88 \mu g \\
(\mathrm{~N}=212)\end{array}$ & $\begin{array}{l}\text { REV } 175 \mu g \\
(N=198)\end{array}$ & $\begin{array}{l}\text { Placebo } \\
(\mathrm{N}=209)\end{array}$ & $\begin{array}{l}\text { REV } 88 \mu g \\
(\mathrm{~N}=205)\end{array}$ & $\begin{array}{l}\text { REV } 175 \mu g \\
(\mathrm{~N}=197)\end{array}$ & $\begin{array}{l}\text { Placebo } \\
(\mathrm{N}=208)\end{array}$ \\
\hline Age, $y$, mean (SD) & $63.7(8.90)$ & $64.2(8.60)$ & $64.3(9.12)$ & $63.1(8.81)$ & $63.6(9.19)$ & $63.5(8.91)$ \\
\hline Sex, male, $\mathrm{n}(\%)$ & $115(54.2)$ & $93(47.0)$ & $109(52.2)$ & $103(50.2)$ & $102(51.8)$ & $97(46.6)$ \\
\hline Race, white, n (\%) & $194(91.5)$ & $179(90.4)$ & $191(91.4)$ & $186(90.7)$ & $171(86.8)$ & $188(90.4)$ \\
\hline Mean BMI, $\mathrm{kg} / \mathrm{m}^{2}$, mean (SD) & $29.1(6.2)$ & $29.6(7.2)$ & $29.4(6.6)$ & $29.2(7.7)$ & $28.9(7.0)$ & $29.3(6.9)$ \\
\hline Current Smoker, n (\%) & $102(48.1)$ & $96(48.5)$ & $103(49.3)$ & $97(47.3)$ & $94(47.7)$ & $95(45.7)$ \\
\hline Concurrent ICS Use, $\mathrm{n}(\%)$ & $85(40.1)$ & 89 (44.9) & $86(41.1)$ & 79 (38.5) & $85(43.1)$ & $85(40.9)$ \\
\hline $\begin{array}{l}\text { Concurrent LABA or ICS/LABA Use, } \\
\mathrm{n}(\%)\end{array}$ & $76(35.8)$ & 79 (39.9) & $74(35.4)$ & 77 (37.6) & 74 (37.6) & $73(35.1)$ \\
\hline $\begin{array}{l}\text { Post-ipratropium Percent Predicted } \\
\text { FEV }_{1} \text {, mean (SD) }\end{array}$ & $55.9(12.9)$ & $54.4(14.0)$ & $55.8(13.4)$ & $54.1(13.7)$ & $53.5(13.5)$ & $53.7(14.1)$ \\
\hline $\begin{array}{l}\text { Post-ipratropium FEV } 1 \text { to FVC Ratio, } \\
\text { mean (SD) }\end{array}$ & $0.6(0.1)$ & $0.5(0.1)$ & $0.5(0.1)$ & $0.5(0.1)$ & $0.5(0.1)$ & $0.5(0.1)$ \\
\hline Baseline FEV $_{1}, \mathbf{L}$, mean (SD) & $1.4(0.5)$ & $1.3(0.4)$ & $1.4(0.5)$ & $1.3(0.5)$ & $1.3(0.5)$ & $1.3(0.5)$ \\
\hline $\begin{array}{l}\text { Proportion of Patients with Baseline } \\
\text { mMRC } \geq 2, n(\%)\end{array}$ & $108(50.9)$ & $83(41.9)$ & $111(53.1)$ & $112(54.6)$ & $101(51.3)$ & $106(51.0)$ \\
\hline $\begin{array}{l}\text { Proportion of Patients with Baseline } \\
\text { CAT } \geq 10, n(\%)\end{array}$ & 194 (91.5) & 170 (85.9) & 187 (89.5) & $189(92.2)$ & $176(89.3)$ & 189 (90.9) \\
\hline $\begin{array}{l}\text { Proportion of Patients with } 0 \\
\text { Exacerbations in Prior Year, n (\%) }\end{array}$ & 165 (77.8) & $160(80.8)$ & $175(83.7)$ & $145(70.7)$ & $148(75.1)$ & $148(71.2)$ \\
\hline $\begin{array}{l}\text { Proportion of Patients with } 1 \\
\text { Exacerbation in Prior Year, } \mathrm{n}(\%)\end{array}$ & 38 (17.9) & 32 (16.2) & 27 (12.9) & 44 (21.5) & 34 (17.3) & 33 (15.9) \\
\hline $\begin{array}{l}\text { Proportion of Patients with } \geq 2 \\
\text { Exacerbations in Prior Year, } n(\%)\end{array}$ & $9(4.2)$ & $6(3.0)$ & $7(3.3)$ & $16(7.8)$ & 15 (7.6) & $27(13.0)$ \\
\hline
\end{tabular}

\section{Efficacy}

\section{Primary Endpoint}

Revefenacin (88 $\mu \mathrm{g}$ and $175 \mu \mathrm{g})$ improved day 85 baseline-adjusted mean trough $\mathrm{FEV}_{1}$ compared with placebo in both Study 0126 and Study 0127 (Figure 2A). In Study 0126, the placebo-adjusted least squares (LS) mean increase in trough $\mathrm{FEV}_{1}$ was $79.2 \mathrm{~mL}$ for revefenacin $88 \mu \mathrm{g}(p=0.0003)$ and $146.3 \mathrm{~mL}$ for revefenacin $175 \mu \mathrm{g}(p<0.0001)$. In Study 0127, the LS mean increase in trough $\mathrm{FEV}_{1}$ with revefenacin was $160.5 \mathrm{~mL}(88 \mu \mathrm{g})$ and $147.0 \mathrm{~mL}(175 \mu \mathrm{g})$ (both $p<0.0001)$. Analysis of pooled Study 0126 and Study 0127 results revealed placebo-adjusted increases in trough $\mathrm{FEV}_{1}$ of $119.8 \mathrm{~mL}(88 \mu \mathrm{g})$ and $148.1 \mathrm{~mL}(175$ $\mu \mathrm{g})$, respectively; the $28.3 \mathrm{~mL}$ difference in trough $\mathrm{FEV}_{1}$ between the revefenacin $88 \mu \mathrm{g}$ and $175 \mu \mathrm{g}$ doses was not statistically significant $(p=0.088)$.

\section{Secondary Endpoints}

Revefenacin increased OTE trough $\mathrm{FEV}_{1}$ by $\geq 100 \mathrm{~mL}$ compared with placebo in both Study 0126 and Study 0127 (Figure 2B). Analysis of pooled Study 0126 and Study 0127 results revealed placebo-adjusted increases in OTE FEV 1 of $115.3 \mathrm{~mL}(88 \mu \mathrm{g})$ and 142.3 $\mathrm{mL}(175 \mu \mathrm{g})$. In addition, revefenacin increased trough $\mathrm{FEV}_{1}$ by $\geq 100 \mathrm{~mL}$ on days $15,29,57,84$ and 85 versus placebo at both the $88 \mu \mathrm{g}$ and $175 \mu \mathrm{g}$ dose (Figure 3).

A significant increase in $\mathrm{FEV}_{1}$ occurred within 2 hours of the first treatment with revefenacin in both studies. Analysis of pooled study results revealed placebo-adjusted LS mean increases in peak $\mathrm{FEV}_{1}(0-2$ hours after first dose) of $127.3 \mathrm{~mL}(88 \mu \mathrm{g})$ and 129.5 $\mathrm{mL}(175 \mu \mathrm{g})$ (both $p<0.0001)$.

Patient Sub-group Analysis

Analysis of pooled Study 0126 and Study 0127 
Figure 2. Placebo-Adjusted Increase in Day 85 Trough Forced Expiratory Volume in 1 Second $(A)^{a}$ and Overall Treatment Effect on Trough Forced Expiratory Volume in 1 Second $(B)^{b}$
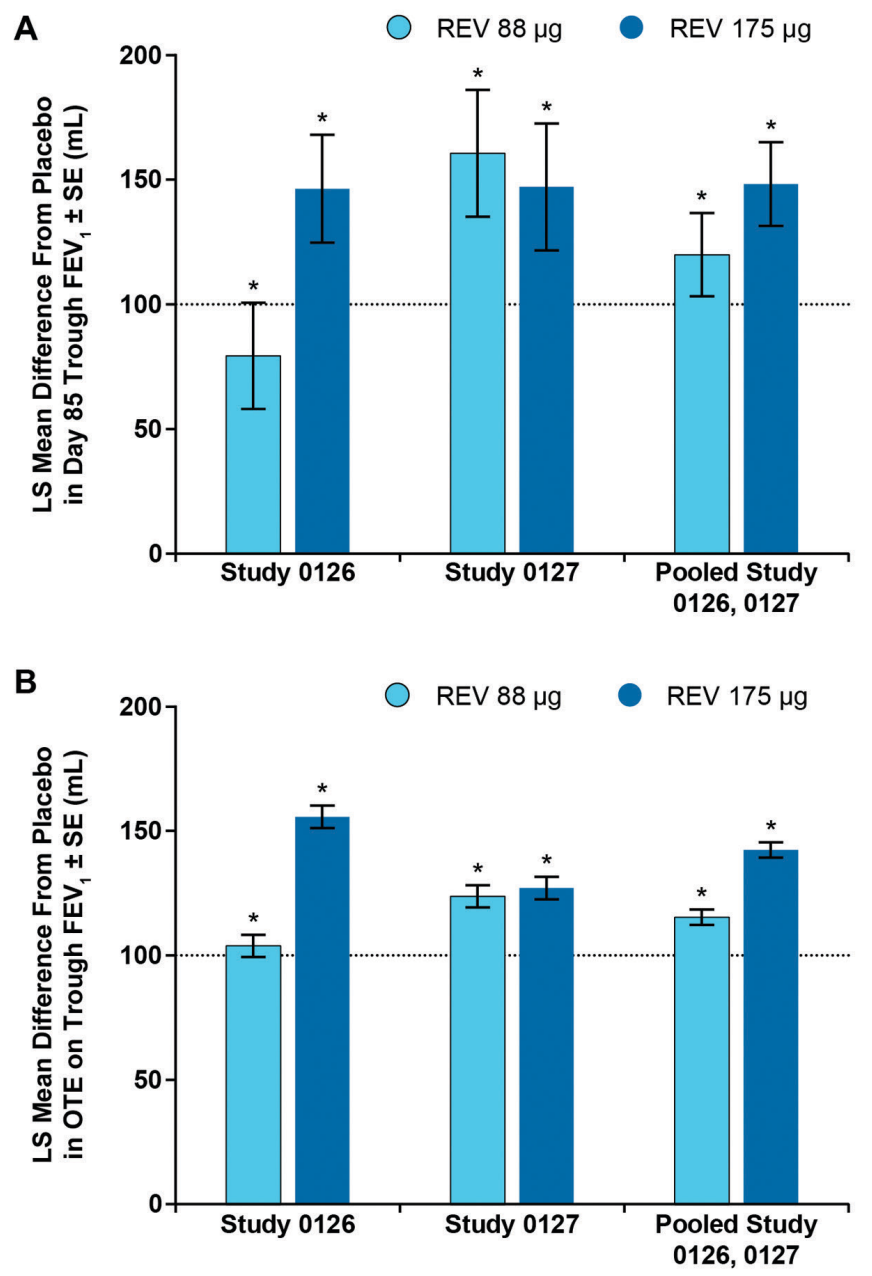

${ }^{*} p<0.001$ versus placebo.

aDay 85 trough $\mathrm{FEV}_{1}$ was the average of values obtained at 23.25 and 23.75 hours following the 84th dose.

${ }^{b}$ Overall treatment effect is an inverse weighted mean of trough

$\mathrm{FEV}_{1}$ over the day 15 to 85 dosing period.

Dotted line $=$ minimal clinically important difference. ${ }^{20}$

$\mathrm{FEV}_{1}=$ forced expiratory volume in 1 second; LS=least squares;

$\mathrm{OTE}=$ overall treatment effect; $\mathrm{REV}=$ revefenacin; $\mathrm{SE}=$ standard error

results showed revefenacin $175 \mu$ g produced greater improvements in day 85 trough $\mathrm{FEV}_{1}$ than revefenacin $88 \mu \mathrm{g}$. The patients in the $175 \mu \mathrm{g}$ group likely had more severe COPD, because this group included those taking concomitant LABA therapy along with ICSs, those $>65$ years of age, in 2011 GOLD category D, ${ }^{18}$

\section{Figure 3. Sustained Increase in Trough Forced Expiratory Volume in 1 Second with Revefenacin ${ }^{\mathrm{a}}$}

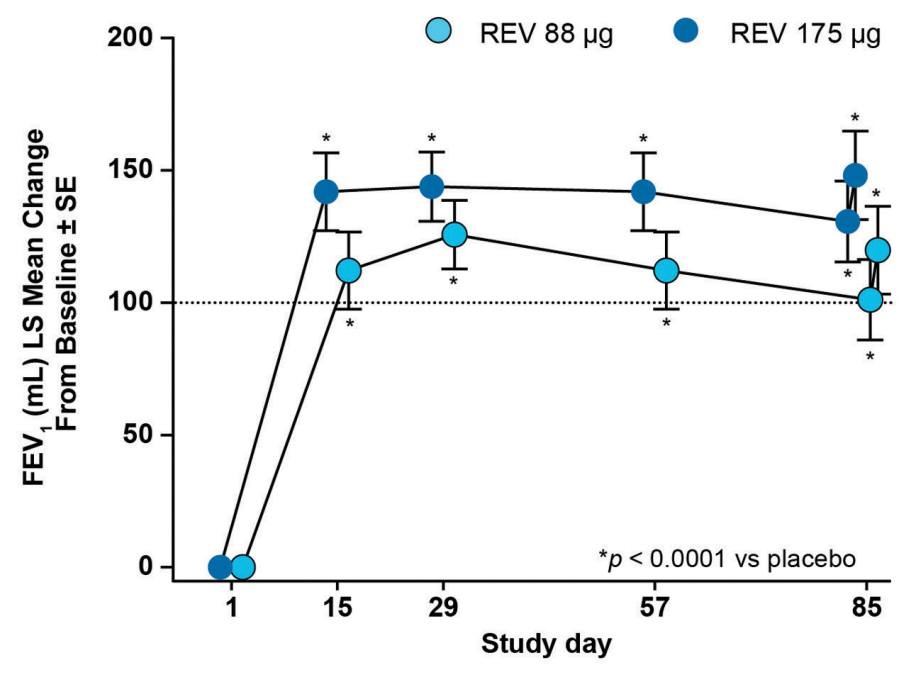

${ }^{*} p<0.0001$ versus placebo.

astudy 0126 and Study 0127 pooled data; number of evaluable study day patients ranged from $n=310$ to $n=359$.

Dotted line $=$ minimal clinically important difference. ${ }^{20}$

$\mathrm{FEV}_{1}=$ forced expiratory volume in 1 second; $\mathrm{LS}=$ least squares; $\mathrm{REV}=$ revefenacin; $\mathrm{SE}=$ standard error

with a modified Medical Research Council dyspnea scale $\geq 2$ and former smokers. Nevertheless, both doses were significantly superior to placebo (Figure 4).

\section{Safety}

The overall incidence of treatment-emergent AEs was similar in the revefenacin ( $88 \mu \mathrm{g}$ and $175 \mu \mathrm{g}$ ) and placebo treatment groups for Study 0126 and Study 0127 (Table 2). Approximately 47\% to 57\% of patients by treatment group reported at least $1 \mathrm{AE}$. COPD (worsening/exacerbation) was the highest-incidence $\mathrm{AE}(\leq 12.2 \%)$. Headache $(\leq 6.8 \%)$, respiratory infection $(\leq 6.6 \%)$, dyspnea $(\leq 5.7 \%)$ and cough $(\leq 5.1 \%)$ were the next most common AEs, with similar frequencies between treatment groups.

Antimuscarinic-related AEs were both infrequent and evenly distributed between treatment groups, including placebo, in both studies, with no patient in either study experiencing more than 1 antimuscarinic AE. The most common antimuscarinic AEs were constipation and dry mouth. A total of 6 patients, between both studies, reported constipation (Study 0126: 1 in the revefenacin $88 \mu \mathrm{g}$ group and 2 in the 


\section{Figure 4. Day 85 Trough Forced Expiratory Volume in 1 Second by Patient Sub-Group ${ }^{\mathrm{a}}$}

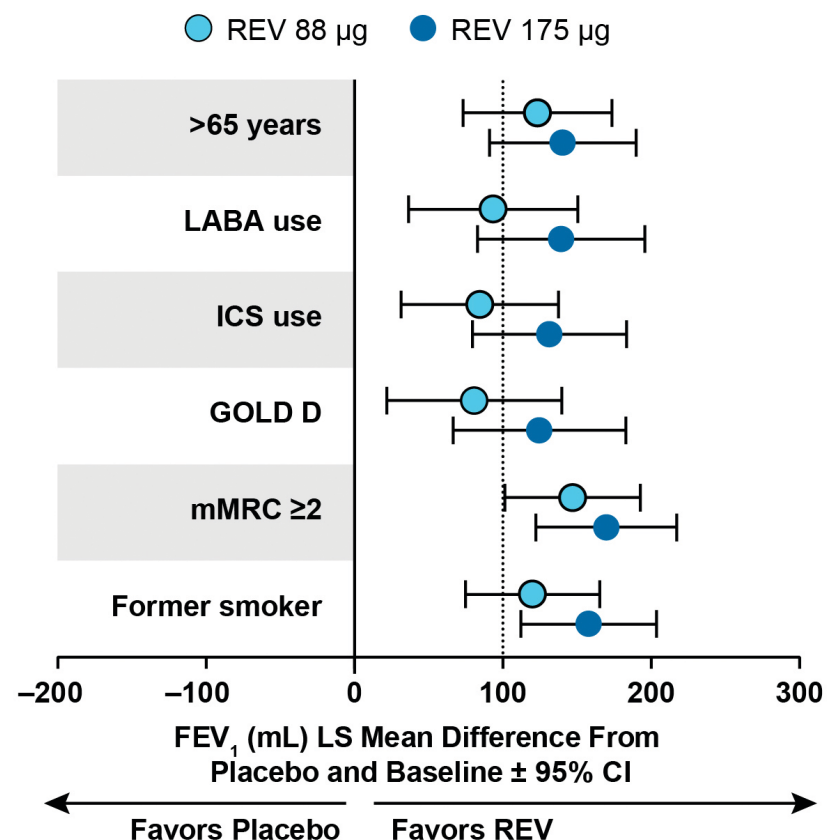

${ }^{\text {a Study }} 0126$ and Study 0127 pooled data; day 85 trough $\mathrm{FEV}_{1}$ was the average of values obtained at 23.25 and 23.75 hours following the 84th dose; number of evaluable sub-group patients ranged from $n=97$ to $n=164$.

Dotted line: minimal clinically important difference. ${ }^{20}$

$\mathrm{CI}=$ confidence interval; $\mathrm{FEV}_{1}=$ forced expiratory volume in 1 second; GOLD D=2011 Global initiative for chronic Obstructive Lung Disease category D; ICS=inhaled corticosteroid; LABA=long-acting beta2-agonist; LS=least squares; mMRC=modified Medical Research Council dyspnea scale; $\mathrm{REV}=$ revefenacin

$175 \mu \mathrm{g}$ group; Study 0127: 1 in the placebo group, 2 in the $88 \mu \mathrm{g}$ group) and dry mouth was reported in 4 patients (Study 0126: 2 patients in the $175 \mu \mathrm{g}$ group; Study 0127: 1 patient each in the $88 \mu \mathrm{g}$ and $175 \mu \mathrm{g}$ groups).

The overall incidence of serious AEs (SAEs) was similar for revefenacin and placebo in Study 0126 ( $\leq$ $6.7 \%$ ) and Study 0127 ( $\leq 5.4 \%$ ) (Table 2). In Study 0126, 1 SAE, a case of worsening/exacerbation of COPD in the $175 \mu \mathrm{g}$ group, was considered by the investigator to be treatment related, while in Study 0127, $1 \mathrm{SAE}$ of pneumonia in the revefenacin $175 \mu \mathrm{g}$ group was considered to be related to the study drug; no other SAEs were considered study-drug related.

Five events over the course of both Study 0126 and Study 0127 met major adverse event criteria. In Study
0126, 1 cardiovascular death occurred in the placebo group, 1 myocardial infarction/unstable angina event occurred in both the $88 \mu \mathrm{g}$ and $175 \mu \mathrm{g}$ groups and 1 arrhythmia event occurred in the $88 \mu \mathrm{g}$ group. In Study 0127, 1 non-cardiovascular death (homicide) occurred in the $175 \mu \mathrm{g}$ group. A pre-specified adjudication of all major adverse cardiac adverse events in the Phase III program by an independent external clinical events committee (the Duke Clinical Research Institute) determined that none of the cardiovascular events was related to the study drug.

\section{Discussion}

Studies 0126 and 0127 both met their primary endpoint of increased trough $\mathrm{FEV}_{1}$ compared with placebo after 12 weeks of once-daily revefenacin in patients with moderate to very severe COPD and in those receiving concomitant LABA therapy. The inclusion of patients with very severe $C O P D$ was unique to this monotherapy program as previous studies with revefenacin were conducted in patients with moderate to severe COPD. ${ }^{11,19}$ Both dose levels of revefenacin showed clinically meaningful improvements in trough $F E V_{1}$ over the entire treatment period, while the revefenacin $175 \mu \mathrm{g}$ dose delivered additional benefit over the $88 \mu \mathrm{g}$ dose in the ITT population as well as in key sub-groups, such as patients with markers of more severe disease. For Study 0126, trough FEV 1 technically did not meet the $100 \mathrm{~mL}$ minimal clinically important difference level ${ }^{20}$; however, $40 \%$ of these patients were on a LABA, and minimal clinically important difference only pertains to a comparison with placebo, so the degree of $\mathrm{FEV}_{1}$ improvement would be expected to be lower. The efficacy results from the 2 studies were consistent with previous studies of revefenacin, including a 4-week Phase II trial in which revefenacin demonstrated significant improvements in trough FEV 1 compared with placebo. ${ }^{11,19}$ Moreover, the trough $\mathrm{FEV}_{1}$ improvements with the $88 \mu \mathrm{g}$ and 175 $\mu \mathrm{g}$ dose $(119 \mathrm{~mL}$ and $148 \mathrm{~mL}$, respectively [pooled study results]) are comparable with reported values for another long-acting bronchodilator, tiotropium, approved for the treatment of COPD. ${ }^{21}$

While the $88 \mu \mathrm{g}$ and $175 \mu \mathrm{g}$ doses met the prespecified primary endpoint in both studies, there were differences in response to the $88 \mu \mathrm{g}$ dose between the 2 studies, though there were no clear differences in baseline characteristics between them. One possibility 


\section{Table 2. Treatment-Emergent Adverse Events ${ }^{\mathrm{a}}$ and Serious Adverse Events in Studies 0126 and 0127}

\begin{tabular}{|c|c|c|c|c|c|c|}
\hline \multirow{2}{*}{$\begin{array}{l}\text { Patients with an AE, n (\%) MedDRA } \\
\text { Preferred Term }\end{array}$} & \multicolumn{3}{|c|}{ Study 0126} & \multicolumn{3}{|c|}{ Study 0127} \\
\hline & $\begin{array}{c}\text { REV } 88 \mu g \\
(\mathrm{~N}=212)\end{array}$ & $\begin{array}{l}\text { REV } 175 \mu g \\
(\mathrm{~N}=198)\end{array}$ & $\begin{array}{l}\text { Placebo } \\
(\mathrm{N}=209)\end{array}$ & $\begin{array}{l}\text { REV } 88 \mu g \\
(\mathrm{~N}=205)\end{array}$ & $\begin{array}{l}\text { REV } 175 \mu \mathrm{g} \\
\left(\mathrm{N}=197^{\mathrm{b}}\right)\end{array}$ & $\begin{array}{l}\text { Placebo } \\
(\mathrm{N}=209)\end{array}$ \\
\hline Any $\mathbf{A E}$ & $110(51.9)$ & $101(51.0)$ & $108(51.7)$ & $116(56.6)$ & $102(51.8)$ & 98 (46.9) \\
\hline COPD (worsening/ exacerbation) & $17(8.0)$ & $21(10.6)$ & $23(11.0)$ & 25 (12.2) & $21(10.7)$ & $25(12.0)$ \\
\hline Headache & $7(3.3)$ & $8(4.0)$ & $5(2.4)$ & $14(6.8)$ & $8(4.1)$ & $6(2.9)$ \\
\hline Upper Respiratory Tract Infection & 14 (6.6) & $1(0.5)$ & $4(1.9)$ & $6(2.9)$ & $10(5.1)$ & $5(2.4)$ \\
\hline Dyspnea & $7(3.3)$ & $4(2.0)$ & $11(5.3)$ & $6(2.9)$ & $8(4.1)$ & $12(5.7)$ \\
\hline Cough & $8(3.8)$ & $7(3.5)$ & $8(3.8)$ & $9(4.4)$ & $10(5.1)$ & $9(4.3)$ \\
\hline Nasopharyngitis & $7(3.3)$ & $6(3.0)$ & $5(2.4)$ & $7(3.4)$ & $9(4.6)$ & $4(1.9)$ \\
\hline Sinusitis & $3(1.4)$ & $5(2.5)$ & $6(2.9)$ & $2(1.0)$ & $4(2.0)$ & $4(2.0)$ \\
\hline Oropharyngeal Pain & $6(2.8)$ & $4(2.0)$ & $1(0.5)$ & $3(1.5)$ & $2(1.0)$ & $5(2.4)$ \\
\hline Urinary Tract Infection & $6(2.8)$ & $2(1.0)$ & $3(1.4)$ & $3(1.5)$ & $2(1.0)$ & $4(1.9)$ \\
\hline Diarrhea & $6(2.8)$ & $1(0.5)$ & $3(1.4)$ & $2(1.0)$ & $3(1.5)$ & $2(1.0)$ \\
\hline Hypertension & $3(1.4)$ & $3(1.5)$ & $3(1.4)$ & $5(2.4)$ & $4(2.0)$ & $2(1.0)$ \\
\hline Acute Sinusitis & $3(1.4)$ & $3(1.5)$ & $1(0.5)$ & - & - & - \\
\hline Muscle Spasms & $4(1.9)$ & $1(0.5)$ & $2(1.0)$ & - & - & - \\
\hline Vomiting & $2(0.9)$ & $3(1.5)$ & $2(1.0)$ & - & - & - \\
\hline Nasal Congestion & - & - & - & $5(2.4)$ & $2(1.0)$ & $2(1.0)$ \\
\hline Back Pain & - & - & - & $4(2.0)$ & $7(3.6)$ & $3(1.4)$ \\
\hline Dizziness & - & - & - & $4(2.0)$ & $4(2.0)$ & 0 \\
\hline \multicolumn{7}{|l|}{ Patients with an SAE, $\mathbf{n}(\%)$} \\
\hline Any SAE & $10(4.7)$ & $10(5.1)$ & $14(6.7)$ & $11(5.4)$ & $5(2.5)$ & 7 (3.3) \\
\hline COPD (worsening/exacerbation) & 0 & $4(2.0)$ & $2(1.0)$ & $8(3.9)$ & $1(0.5)$ & $4(1.9)$ \\
\hline Chest Pain & $1(0.5)$ & $1(0.5)$ & 0 & $1(0.5)$ & 0 & 0 \\
\hline Cellulitis & $1(0.5)$ & 0 & 0 & $1(0.5)$ & 0 & $1(0.5)$ \\
\hline Acute Myocardial Infarction & $1(0.5)$ & $1(0.5)$ & 0 & 0 & 0 & 0 \\
\hline Upper GI Hemorrhage & $1(0.5)$ & $1(0.5)$ & 0 & 0 & 0 & 0 \\
\hline Noncardiac Chest Pain & 0 & $1(0.5)$ & $1(0.5)$ & 0 & 0 & 0 \\
\hline Acute Respiratory Failure & 0 & 0 & 0 & $2(1.0)$ & 0 & 0 \\
\hline Respiratory Failure & 0 & 0 & $1(0.5)$ & $1(0.5)$ & 0 & 0 \\
\hline \multicolumn{7}{|c|}{ Patients with an Antimuscarinic-related $\mathrm{AE},{ }^{\mathrm{c}} \mathbf{n}(\%)$} \\
\hline Constipation & $1(0.5)$ & $2(1.0)$ & 0 & $2(1.0)$ & 0 & $1(0.5)$ \\
\hline Dry Mouth & 0 & $2(1.0)$ & 0 & $1(0.5)$ & $1(0.5)$ & 0 \\
\hline Dysuria & 0 & 0 & 0 & $2(1.0)$ & 0 & 0 \\
\hline
\end{tabular}

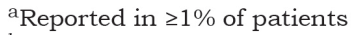

${ }^{\mathrm{b}}$ One patient in the $175 \mu \mathrm{g}$ group received both $175 \mu \mathrm{g}$ and placebo doses during study due to site error in study drug dispensation. This patient contributed to both the $175 \mu \mathrm{g}$ group and the placebo group for the safety analyses, and thus is counted twice in the safety analysis set.

${ }^{\mathrm{C}}$ The preferred terms for treatment-emergent AEs that were considered antimuscarinic were constipation, dry mouth, dysuria, worsening of urinary retention, and worsening of narrow-angle glaucoma.

$\mathrm{AE}=$ adverse event; MedDRA=Medical Dictionary for Regulatory Activities; REV=revefenacin; $\mathrm{SAE}=$ serious adverse event; $\mathrm{COPD}=$ chronic obstructive pulmonary disease; $\mathrm{GI}=$ gastrointestinal

for the differences is that the lower dose was at the lower edge of the dose-response curve and some patients in the one study might not have received the full benefit of the drug, which was corrected by the higher dose. This suggests that the higher dose would be the more optimal dose for all participants, especially as there were no added safety concerns with the higher dose. In addition, the LS mean difference from placebo in trough $\mathrm{FEV}_{1}$ at Day 85 was slightly higher for the $88 \mu \mathrm{g}$ dose than the $175 \mu \mathrm{g}$ dose in Study 0127. This result was a single time point. In the pooled results (studies 0126 and 0127), the LS mean difference for 
placebo in trough $\mathrm{FEV}_{1}$ at Day 85 was higher for the revefenacin $175 \mu \mathrm{g}$ dose than for the revefenacin $88 \mu \mathrm{g}$ dose. Therefore, it is possible that there is an additional response with the revefenacin $175 \mu \mathrm{g}$ dose.

Revefenacin also demonstrated a desirable safety and tolerability profile for both doses in both studies, which was consistent with previous studies of revefenacin in patients with COPD. ${ }^{11,19}$ In addition, a low incidence of antimuscarinic AEs was observed. This finding is consistent with revefenacin's pharmacologic properties of competitive antagonism of the $\mathrm{M} 3$ receptor, unique molecular class (i.e., it is not a quaternary ammonia) and lung-selective design, 7,8 as well as with results from previous clinical studies. ${ }^{11,19}$ The safety profile was supported by a prior pre-clinical study ${ }^{8}$ that revealed revefenacin's superior functional lung selectivity index (ratio of bronchoprotective versus antisialagogue potency) compared with either glycopyrronium or tiotropium, with dose-dependent, 24-hour bronchoprotection that was maintained after 7 days of once-daily dosing in animal models of bronchoconstriction. Pooled results from Study 0126 and Study 0127 were similar to each individual study with regard to efficacy and safety outcomes.

Limitations of the replicate studies include the treatment period being only approximately 3 months, which does not allow for conclusions regarding longterm treatment. Although study patients were provided with rescue medication that could potentially impact outcomes, reductions for both revefenacin doses in the average number of rescue medication puffs per day used, while not statistically significant, showed trends in favor of revefenacin over placebo and supported the results of the primary endpoint (data not shown). Results from a 52-week safety study of revefenacin in COPD (to be published separately) should help elucidate revefenacin's long-term safety profile. Additionally, the subgroup analysis results should be interpreted with caution due to the smaller sample sizes in each subgroup.

A key strength of the studies, apart from their blinded and controlled design, is that they were replicate studies that observed similar results for both primary and secondary endpoints, thereby adding consistency and validity to their outcomes. Furthermore, compared with placebo, both revefenacin doses in the pooled analysis increased trough $\mathrm{FEV}_{1}$ by $>100 \mathrm{~mL}$, a level of bronchodilation that has previously been suggested as a minimally clinically important difference for $\mathrm{FEV}_{1}{ }^{20}$
As a novel once-daily LAMA for nebulization, revefenacin may be differentiated from the currently available once-daily tiotropium and umeclidinium handheld products in important ways. Revefenacin's novel biphenyl carbamate tertiatry amine structure is distinct from the quaternary ammonium antagonists (e.g., tiotropium and umeclidinium), ${ }^{22}$ thus representing the first inhaled LAMA of its class in clinical development for COPD. Revefenacin is a LAMA endowed with chemical stability (enabling long-term storage as a preservative-free aqueous solution product), high lung-to-salivary gland functional selectivity (vida infra) and a metabolically labile primary amide "soft-drug" site to allow rapid systemic clearance of the parent drug, thus potentially minimizing systemically mediated AEs. ${ }^{7}$

While the high metabolic lability of revefenacin contrasts with the relative metabolic stability of tiotropium and its primarily renal systemic clearance profile, revefenacin shares umeclidinium's profile of rapid metabolic turnover after distributing from the lung. ${ }^{23}$ Systemic clearance of revefenacin is primarily via enzymatic hydrolysis (versus cytochrome P450 [CYP2D6]-mediated oxidative turnover for umeclidinium). ${ }^{24}$ Finally, the revefenacin drug product in the current study was administered via a standard jet nebulizer, and this unique presentation of a once-daily bronchodilator may be of future therapeutic benefit to those patients who prefer or require nebulization therapy. $^{4}$

\section{Conclusion}

Revefenacin (88 $\mu \mathrm{g}$ and $175 \mu \mathrm{g}$ ), administered once daily for 12 weeks to patients with moderate to very severe COPD, demonstrated clinically significant improvements in trough $\mathrm{FEV}_{1}$, as well as OTE FEV over the entire treatment period. Revefenacin 175 $\mu \mathrm{g}$ demonstrated greater improvements in $\mathrm{FEV}_{1}$ in concomitant LABA patients and in more severe patients than revefenacin $88 \mu \mathrm{g}$. Revefenacin has the potential to be the first once-daily, long-acting bronchodilator for use in patients who require or prefer nebulized antimuscarinic therapy.

\section{Acknowledgments}

This study was funded by Theravance Biopharma R\&D, Inc., (Dublin, Ireland). The authors acknowledge Roger Hill, PhD, and Gautam Bijur, PhD, for medical 
writing and Paula Stuckart for editorial assistance in the preparation of the manuscript (Ashfield Healthcare Communications, Middletown, Connecticut).

Author contributions: GTF takes responsibility for the content of this article, including the data and analysis. GTF, GF, KKP participated in data acquisition and data analysis/interpretation. CNB, EJM, BH, SP, GC participated in study design, data acquisition and data analysis/interpretation. All authors contributed to manuscript drafting and/or critical revision, approved the final manuscript and agree to be held accountable for all aspects of the work.

\section{Declaration of Interest}

GTF has received grants, served on advisory boards, received consulting fees and/or received speaking fees from AstraZeneca, Boehringer Ingelheim, Circassia, Forest, GlaxoSmithKline, Innoviva, Meda, Mylan, Novartis, Pearl Therapeutics, Sanof, Sunovion, Theravance Biopharma and Verona. GF and KKP have nothing to declare. CNB, EJM, BH, SP and GC are employees of Theravance Biopharma US, Inc. Mylan Inc., (Canonsburg, Pennsylvania) and Theravance Biopharma US, Inc., (South San Francisco, California) funded medical writing support. 


\section{References}

1. Vogelmeier CF, Criner GJ, Martinez FJ, et al. Global strategy for the diagnosis, management, and prevention of chronic obstructive lung disease 2017 report. GOLD executive summary. Am J Respir Crit Care Med. 2017;195(5):557-582. doi: https://doi.org/10.1164/rccm.201701-0218PP

2. Bonini M, Usmani OS. The importance of inhaler devices in the treatment of COPD. COPD Res Pract. 2015;1(1):1-9. doi: https://doi.org/10.1186/s40749-015-0011-0

3. Lavorini F, Corrigan CJ, Barnes PJ, et al. Retail sales of inhalation devices in European countries: so much for a global policy. Respir Med. 2011;105(7):1099-1103.

doi: https://doi.org/10.1016/j.rmed.2011.03.012

4. Tashkin DP. A review of nebulized drug delivery in COPD. Int $J$ Chron Obstruct Pulmon Dis. 2016;11:2585-2596. doi: https://doi.org/10.2147/COPD.S114034

5. Dhand R, Dolovich M, Chipps B, Myers TR, Restrepo R, Farrar $\mathrm{JR}$. The role of nebulized therapy in the management of COPD: evidence and recommendations. COPD. 2012;9(1):58-72. doi: https://doi.org/10.3109/15412555.2011.630047

6. Pritchard JN. Nebulized drug delivery in respiratory medicine: what does the future hold? Ther Deliv. 2017;8(6):391-399. doi: https://doi.org/10.4155/tde-2017-0015

7. Ji Y, Husfeld C, Pulido-Rios MT, et al. Duration by design: discovery of revefenacin, the first-in-class nebulized oncedaily bronchodilator for the treatment of patients with COPD [abstract]. Chest. 2016;150(Suppl 4):970A. doi: https://doi.org/10.1016/j.chest.2016.08.1074

8. Pulido-Rios MT, McNamara A, Obedencio GP, et al. In vivo pharmacological characterization of TD-4208, a novel lungselective inhaled muscarinic antagonist with sustained bronchoprotective effect in experimental animal models. $J$ Pharmacol Exp Ther. 2013;346(2):241-250. doi: https://doi.org/10.1124/jpet.113.203554

9. Baldwin M, McConn D, Potgieter P, Steinfeld T, Quinn D, Moran E. Single-dose pharmacokinetics of TD-4208, a novel longacting muscarinic antagonist, in patients with COPD [abstract]. Am J Respir Crit Care Med. 2013;187:A1496.

10. Steinfeld T, Pulido-Rios M, Chin K, et al. In vitro characterization of TD-4208, a lung-selective and long-acting muscarinic antagonist bronchodilator [abstract]. Am J Respir Crit Care Med. 2009;179:A4553.

doi: https://doi.org/10.1164/ajrccm-conference.2009.179.1_Meet ingAbstracts.A4553

11. Pudi KK, Barnes CN, Moran EJ, Haumann B, Kerwin E. A 28day, randomized, double-blind, placebo-controlled, parallel group study of nebulized revefenacin in patients with chronic obstructive pulmonary disease. Respir Res. 2017;18(1):182. doi: https://doi.org/10.1186/s12931-017-0647-1
12. International Council for Harmonisation of Technical Requirements for Pharmaceuticals for Human Use (ICH). Integrated addendum to ICH E6(rR1): guideline for good clinical practice E6 (R2). ICH website. http://www.ich.org/fileadmin/ Public_Web_Site/ICH_Products/Guidelines/Efficacy/E6/E6_ R2_Addendum_Step2.pdf Published June 11, 2015. Accessed July 6, 2018.

13. World Medical Association. World Medical Association Declaration of Helsinki: ethical principles for medical research involving human subjects. JAMA. 2013;310(20):2191-2194. doi: https://doi.org/10.1001/jama.2013.281053

14. New York Heart Association (NYHA). Classes of heart failureNYHA Functional Classification. American Heart Association website. http://www.heart.org/HEARTORG/Conditions/Heart Failure/AboutHeartFailure/Classes-of-Heart-Failure_ UCM_306328_Article.jsp\#.WN8RO_nys2w Published 2017. Accessed March 2019.

15. Jones PW, Quirk FH, Baveystock CM. The St George's Respiratory Questionnaire. Respir Med. 1991;85(Suppl B):25-31; discussion 33-37.

16. Mahler DA, Ward J, Fierro-Carrion G, et al. Development of self-administered versions of modified baseline and transition dyspnea indexes in COPD. COPD. 2004;1(2):165-172. doi: https://doi.org/10.1081/COPD-120030829

17. Brown EG, Wood L, Wood S. The medical dictionary for regulatory activities (MedDRA). Drug Safety. 1999;20(2):109117. doi: https://doi.org/10.2165/00002018-199920020-00002

18. Vestbo J, Hurd SS, Agustí AG, et al. Global strategy for the diagnosis, management, and prevention of chronic obstructive pulmonary disease. Am J Respir Crit Care Med. 2013;187(4):347365. doi: https://doi.org/10.1164/rccm.201204-0596PP

19. Quinn D, Barnes CN, Yates W, et al. Pharmacodynamics, pharmacokinetics and safety of revefenacin (TD-4208), a long-acting muscarinic antagonist, in patients with chronic obstructive pulmonary disease (COPD): Results of two randomized, double-blind, phase 2 studies. Pulm Pharmacol Ther. 2018;48:71-79.

doi: https://doi.org/10.1016/j.pupt.2017.10.003

20. Jones PW, Beeh KM, Chapman KR, Decramer M, Mahler DA, Wedzicha JA. Minimal clinically important differences in pharmacological trials. Am J Respir Crit Care Med. 2014; 189(3):250-255.

doi: https://doi.org/10.1164/rccm.201310-1863PP

21. van Noord JA, Cornelissen PJ, Aumann JL, Platz J, Mueller A, Fogarty C. The efficacy of tiotropium administered via Respimat Soft Mist Inhaler or HandiHaler in COPD patients. Respir Med. 2009; 103(1):22-29.

doi: https://doi.org/10.1016/j.rmed.2008.10.002 
22. Montuschi P, Ciabattoni G. Bronchodilating drugs for chronic obstructive pulmonary disease: current status and future trends. J Med Chem. 2015;58(10):4131-4164.

doi: https://doi.org/10.1021/jm5013227

23. Babu KS, Morjaria JB. Umeclidinium in chronic obstructive pulmonary disease: latest evidence and place in therapy. Ther Adv Chronic Dis. 2017;8(4-5):81-91.

doi: https://doi.org/10.1177/2040622317700822

24. GlaxoSmithKline (GSK). Incruse Ellipta ${ }^{\circledR}$ (umeclidinium inhalation powder) [prescribing information]. Research Triangle Park. GSK website. https://www.gsksource.com/ pharma/content/dam/GlaxoSmithKline/US/en/Prescribing_ Information/Incruse_Ellipta/pdf/INCRUSE-ELLIPTA-PI-PIL. PDF Published October 2017. Accessed July 6, 2018. 